\title{
Inhibition of Src tyrosine kinase stimulates adrenal androgen production
}

\author{
R Sirianni ${ }^{1,2}$, B R Carr ${ }^{1}$, S Andò ${ }^{2}$ and W E Rainey ${ }^{\mathbf{1}}$ \\ ${ }^{1}$ Division of Reproductive Endocrinology, University of Texas Southwestern Medical Center, 5323 Harry Hines Boulevard, Dallas, \\ Texas 75390-9032, USA \\ ${ }^{2}$ Faculty of Pharmacy, University of Calabria, Arcavacata di Rende (CS) Italy
}

(Requests for offprints should be addressed to W E Rainey)

\begin{abstract}
A unique characteristic of the primate adrenal is the ability to produce 19-carbon steroids, often called the adrenal androgens. Although it is clear that the major human adrenal androgens, dehydroepiandrosterone (DHEA) and DHEA sulfate (DHEA-S), are produced almost solely in the adrenal reticularis, the mechanisms regulating production are poorly understood. Herein, we tested the hypothesis that the Src family of tyrosine kinases are involved in the regulation of adrenal androgen production. The $\mathrm{NCl}-\mathrm{H} 295 \mathrm{R}$ human adrenal cell line and primary human adrenal cells in culture were used to study adrenal androgen production and expression of enzymes involved in steroidogenesis. To examine the role of Src tyrosine kinase, cells were treated with PP2, a specific Src inhibitor. Alternatively, adrenal cells were transfected with an expression vector containing a dominant-negative form of Src. PP2 treatment inhibited basal cortisol production while significantly increasing the production of DHEA and DHEA-S (together referred to as $\operatorname{DHEA}(\mathrm{S})$ ) in both adrenal cell models. The effect of PP2 on steroidogenesis occurred along with a rapid induction of steroidogenic acute regulatory (StAR) protein synthesis as revealed by Western analysis. Treatment with PP2 also increased mRNA levels for StAR, and cholesterol side-chain cleavage (CYP11A) and 17 $\alpha$-hydroxylase/17,20-lyase (CYP17) enzymes. Treatment of adrenal cells with the cAMP agonist dibutyryladenosine cyclic monophosphate (dbcAMP), stimulated the production of cortisol and DHEA(S). However, treatment of adrenal cells with a combination of PP2 and dbcAMP enhanced the production of DHEA(S) while inhibiting cortisol production. During dbcAMP treatment PP2 was able to augment the expression of CYP17 and to inhibit the induction of 3 $\beta$-hydroxysteroid dehydrogenase type 2 (HSD3B2) levels. Increasing the CYP17 to HSD3B2 ratio is likely to promote the use of steroid precursors for the production of DHEA(S) and not for cortisol. Taken together these data suggest that the inhibition of Src tyrosine kinases causes adrenal cells to adopt a reticularis phenotype both by the production of DHEA(S) and by the steroidogenic enzymes expressed.
\end{abstract}

Journal of Molecular Endocrinology (2003) 30, 287-299

\section{Introduction}

Dehydroepiandrosterone (DHEA) represents the major product of most primate adrenal glands (Nieschlag et al. 1973, Guillemette et al. 1996). DHEA is secreted mainly as its sulfoconjugate DHEA sulfate (DHEA-S), which is the most abundant circulating steroid hormone in both men and women. The divergence between the circulating levels of cortisol and both adrenal androgens (together referred to as DHEA(S)) observed during fetal and post-natal life suggests that the production of these steroids occurs, in part, through independent mechanisms (Parker \& Odell 1980, McKenna et al. 1997, Parker et al. 1999). This has led to speculation that hormones of extra-adrenal or intra-adrenal origin might selectively stimulate the production of DHEA(S). The mechanisms that control adrenal production of DHEA(S) are not clearly understood and to date an agonist that selectively stimulates adrenal cell production of DHEA(S) without stimulating cortisol production 
has not been found. However, several factors have been proposed to stimulate $\operatorname{DHEA}(\mathrm{S})$ production, including estradiol (Winter \& Smail 1983, Mesiano \& Jaffe 1993, Gell et al. 1998b), corticotropinreleasing hormone (CRH) (Smith et al. 1998, Chakravorty et al. 1999) and leptin (Biason-Lauber et al. 2000)

While the regulation of $\mathrm{DHEA}(\mathrm{S})$ production remains poorly understood the sites of DHEA(S) synthesis have been well defined. DHEA-S is the principal steroid product of the fetal zone of the human fetal adrenal (Mesiano \& Jaffe 1997a) and the inner zona reticularis of human adult adrenal (Endoh et al. 1996). Recently, the expression patterns of the steroid-metabolizing enzymes within the human fetal, neonatal and adult adrenal have been studied, giving some insight into adrenal androgen production. Of the two enzymes needed for DHEA synthesis, CYP11A (cholesterol sidechain cleavage) and CYP17 (17 $\alpha$-hydroxylase, 17,20-lyase), only the 17,20 lyase activity of GYP17 appears to alter its activity as the adrenal initiates DHEA production at adrenarche (Schiebinger et al. 1981, Suzuki et al. 2000). There also appears to be a negative correlation between the enzyme type II $3 \beta$-hydroxysteroid dehydrogenase (HSD3B2) and DHEA(S) production (Doody et al. 1990, Endoh et al. 1996, Gell et al. 1998a, Suzuki et al. 2000). The correlation is most evident in the fetal adrenal where HSD3B2 expression is very low compared with that observed in the adult (Narasaka et al. 2001, Rainey et al. 2001) but also is seen within the adrenal at adrenarche where the zona reticularis exhibits little HSD3B2 expression. Taken together these studies indicate that cells that produce adrenal androgens exhibit a specific phenotype, in which there is high expression of CYP17 but low expression of HSD3B2. Thus, understanding the mechanisms that positively and negatively regulate the expression of CYP17 and HSD3B2 are of primary importance to defining the physiological mechanisms that regulate DHEA(S) production.

Our approach has been to use the DHEA(S)secreting NCI-H295R (H295R) adrenocortical cell as an in vitro model system to determine intracellular signaling pathways that independently regulate the expression of CYP17 and HSD3B2 (Rainey et al. 1993, Mason et al. 1995). Several agonists have been found that inhibit $\operatorname{DHEA}(\mathrm{S})$ production by stimulating HSD3B2 while inhibiting CYP17 expression (Bird et al. 1996, 1998).
However, the ability to specifically stimulate DHEA(S) biosynthesis while inhibiting cortisol production has remained elusive. Herein, we demonstrate that the inhibition of Src tyrosine kinase increases CYP17 expression while inhibiting agonist-stimulated expression of HSD3B2. In addition, inhibition of Src stimulated the synthesis of adrenal androgens while blocking cortisol production. These studies represent the first to demonstrate a signaling pathway that may play a role in specifically stimulating adrenal production of $\mathrm{DHEA}(\mathrm{S})$.

\section{Materials and methods}

\section{Cell culture}

H295R human adrenal tumor cells were cultured in Dulbecco's modified Eagle's and Ham's F-12 (DME/F12) medium (Gibco BRL, Gaithersburg, MD, USA), supplemented with 2\% Ultroser G (BioSepra SA, Villeneuve la Garenne Cedex, France), 1\% ITS Plus (insulin, $6.25 \mu \mathrm{g} / \mathrm{ml}$; transferrin, $6.25 \mu \mathrm{g} / \mathrm{ml}$; selenium, $6.25 \mathrm{ng} / \mathrm{ml}$; BSA, $1 \cdot 25 \mathrm{mg} / \mathrm{ml}$; linoleic acid, $5.35 \mu \mathrm{g} / \mathrm{ml}$ ) (Collaborative Research, Bedford, MA, USA) and antibiotics as previously described (Rainey et al. 1993). Cell monolayers were subcultured onto 12 -well culture dishes to study steroidogenesis $\left(5 \times 10^{5}\right.$ cells/well $)$ and $100-\mathrm{mm}$ dishes for RNA extraction $\left(7 \times 10^{6}\right.$ cells/plate) and used for experiments $48 \mathrm{~h}$ later. Human adult adrenal glands were obtained after surgical removal. Glands were decapsulated, minced into small pieces and incubated in DME/F12 containing $0 \cdot 1 \%$ collagenase digestion and mechanical dispersion for $1 \mathrm{~h} 30 \mathrm{~min}$ at $37^{\circ} \mathrm{C}$. The dispersed cells were finally digested in medium containing 0.01\% DNase. Cells were then plated onto 12-well culture dishes at a density of $1.5 \times 10^{5}$ per well and used for experiments 6 days later. Human fetal and adult adrenal glands were obtained and used following approval by the Institutional Review Board of the University of Texas Southwestern Medical Center.

\section{Stimulation of steroid secretion and analysis of steroids}

Prior to experiments, cells were maintained overnight in DME/F12 medium containing $0 \cdot 1 \%$ Ultroser $\mathrm{G}$ and antibiotics (low-serum medium). 
Where indicated cells were pre-incubated with Src tyrosine kinase inhibitor, PP2 (CalbiochemNovabiochem Corporation, San Diego, CA, USA), for $30 \mathrm{~min}$ at $37^{\circ} \mathrm{C}$ in fresh low-serum medium. Dibutyryladenosine cyclic monophosphate (dbcAMP) (Sigma-Aldrich, St Louis, MO, USA) was added to the cells and the treatment carried out at $37^{\circ} \mathrm{C}$ for the indicated times. Steroid content of experimental medium was determined using RIA kits (Diagnostic System Laboratories, Webster, TX, USA). Results of steroid assays were normalized to the cellular protein content in each well and expressed as pmol/mg cell protein.

\section{Protein determination}

Cells were lysed in Tris- $\mathrm{HCl}(50 \mathrm{mM}, \mathrm{pH} 7 \cdot 4)$ containing $\mathrm{NaCl}(150 \mathrm{mM})$, SDS (1\%), EGTA $(5 \mathrm{mM}), \mathrm{MgCl}_{2}(0.5 \mathrm{mM}), \mathrm{MnCl}_{2}(0.5 \mathrm{mM})$ and phenylmethylsulfonylfluoride $(0.2 \mathrm{mM})$. The protein contents of samples were then determined by the bicinchoninic acid protein assay, using a BCA Assay kit (Pierce, Rockford, IL, USA).

\section{Protein immunoblot analysis}

PAGE was carried out on the samples using the Novex gel electrophoresis system with 4-12\% bis-tris NuPage gels (Invitrogen, Carlsbad, CA, USA). Proteins were electrophoretically transferred onto PVDF membranes by wet transfer for $1 \mathrm{~h}$ at $25 \mathrm{~V}$. Following transfer, membranes were incubated for $1 \mathrm{~h}$ at room temperature with antibody to steroidogenic acute regulatory protein (StAR) (Pezzi et al. 1996). Membranes were incubated with horseradish peroxidase-conjugated secondary antibodies (Amersham Pharmacia Biotech Inc., Piscataway, NJ, USA) and immunoreactive bands were visualized with the ECL Western blotting detection system (Amersham Pharmacia Biotech). The StAR protein antibody was obtained from Dr Doug Stocco (Texas Tech Medical School, Lubbock, TX) and used at a 1:5000 dilution.

\section{RNA extraction and Northern analysis}

RNA was extracted from cells using an Ultraspec RNA isolation system (Biotecx Laboratories, Inc., Houston, TX, USA). Purity and integrity of the RNA were checked spectroscopically and by gel electrophoresis prior to use. Samples of RNA
$(10 \mu \mathrm{g})$ were separated by electrophoresis on gels containing $1 \%$ agarose in the presence of formaldehyde. RNA was transferred to a nylon membrane (Hybond-N+; Amersham Pharmacia Biotech) by overnight blotting at $10 \mathrm{~V}$ and was cross-linked under UV light. Prehybridization was carried out at $42{ }^{\circ} \mathrm{C}$ for $6 \mathrm{~h}$ as previously described (Bird et al. 1995). Hybridizations were performed in the same composition buffer at $42{ }^{\circ} \mathrm{C}$ for $16 \mathrm{~h}$ using cDNA probes that were developed based on the human sequences. PCR was used to amplify a 500 bp cDNA fragment of the HSD3B2 (Genbank accession number M77144, coding sequence between base 1616 and base 8209), a $301 \mathrm{bp}$ fragment of CYP17 (Genbank accession number M14564, bases 48-349), a 217 bp fragment of StAR (Genbank accession number NM 000349, bases 725-941) and a 406 bp fragment of GYP11A1 (Genbank accession number M14565, bases 1224-1630). Probes were labeled with a Rediprime II DNA Labeling System (Amersham Pharmacia Biotech) and used in a hybridization reaction. After hybridization, blots were washed in $2 \times \mathrm{SSC}$ containing $0 \cdot 1 \% \mathrm{SDS}$ at room temperature for $30 \mathrm{~min}$, then in $0 \cdot 1 \times \mathrm{SSC}$ containing $0.1 \% \operatorname{SDS}$ at $37^{\circ} \mathrm{C}$ for $30 \mathrm{~min}$ and at $42{ }^{\circ} \mathrm{C}$ for $15 \mathrm{~min}$. Quantification of bound probe was determined using phosphoimager analysis (425E; Molecular Dynamics, Amersham Pharmacia Biotech). Membranes were subsequently exposed to $\mathrm{X}$-ray film. Finally, membranes were probed with a 598 bp DNA segment from human glyceraldehyde3-phosphate dehydrogenase $(\mathrm{G} 3 \mathrm{PDH})$ gene (bases 185-782). Bound probe was quantified as described above. G3PDH transcript was used to normalize for variations in loading of RNA on the gels.

\section{Plasmid and electroporation}

The dominant-negative Src plasmid was obtained from Upstate Biotechnology (Waltham, MA, USA) and modified as follows. The dominant-negative Src tyrosine kinase coding sequence was subcloned into pTracer A (Invitrogen), which contains the coding sequence for green fluorescent protein (GFP). The insert was checked by restriction size and sequencing. H295R cells were electroporated using the Gene Pulser system with a capacitance extender (Bio-Rad, Hercules, CA, USA). Cells were electroporated at $250 \mathrm{~V}$ in the presence of $50 \mu \mathrm{g}$ plasmid DNA (pTracer A empty vector or 
dominant-negative Src). Cells $\left(4 \times 10^{7}\right)$ were plated in a 150-mm dish using complete medium, and after 2 days were collected and sorted for green fluorescent cells in a flow cytometer (FACSVantage SE; Becton Dickinson, Franklin Lakes, NJ, USA). Selected cells were solubilized in lysis buffer, and $5 \mu \mathrm{g}$ of total protein were loaded on a gel and then transferred to a membrane as described in the immunoblot analysis method. The blot was incubated sequentially with antibody to CYP17 (1:2500) and Src (1:1000). Immunoreactive bands were visualized with an ECL Western blotting detection system (Amersham Pharmacia Biotech).

\section{Semi-quantitative RT-PCR for Src tyrosine kinases}

A semi-quantitative measurement of the relative abundance of the Src family members, Src, Fyn and Yes, was performed. Total RNA was isolated from H295R cells as described above. The first-strand cDNA synthesis reaction was catalyzed by Superscript II RNase $\mathrm{H}^{-}$reverse transcriptase (Gibco BRL) and primed by oligo $\mathrm{d}(\mathrm{T})$ using $3 \mu \mathrm{g}$ total RNA in a total volume of $20 \mu \mathrm{l}$. In the PCR reaction, human Src family members were detected using gene-specific primers (Src: sense 5'-TAG GAG GGA GAC AGA CGT GT-3', antisense 5'-CTG AGT CTG CGG CTT GGA-3', encompassing a $467 \mathrm{bp}$ fragment; Fyn: sense 5'-TGT GAC CTG CAT CGC CAA-3', antisense 5'-TTT GTG ACA GGG AAC TAC-3', encompassing a 615 bp fragment; Yes: sense 5'-GGA GCA GAA CGC ACT ACA-3', antisense 5'-CTT GTG CGT GAA TGG AAT CTG-3' encompassing a 370 bp fragment). The PGR reaction was performed in a total volume of $50 \mu \mathrm{l}$ using $1.5 \mu \mathrm{l}$ from the original first-strand cDNA synthesis. Before PCR amplification, samples were denatured for $3 \mathrm{~min}$ at $94^{\circ} \mathrm{C}$, then the PCR reaction was programmed as follows: denaturing at $94{ }^{\circ} \mathrm{C}$ for $1 \mathrm{~min}$, annealing at $55^{\circ} \mathrm{C}$ for $1 \mathrm{~min}$ and extension at $72{ }^{\circ} \mathrm{C}$ for $2 \mathrm{~min}$. Because of the exponential nature of PCR amplification, RT-PCR quantification may give false estimates of abundance of the target message. By using a constitutively expressed housekeeping gene, G3 PDH, as a reference gene to normalize mRNA levels and by taking data from the exponential phase of the PGR amplification, it is possible to qualitatively evaluate the abundance of the target message. (G3 PDH specific gene primers: sense 5'-CGA CGC ATG GGA AAT TGG ATG GCA-3', antisense 5'-TCT AGA CGG CAG GTC AGG TCG ACG-3', encompassing a 598 bp fragment). The PCR reactions were terminated at various cycle points to decipher the exponential phase of the PCR amplification. PGR reactions were terminated at 24, 27 and 30 cycles. A semi-quantitative RT-PCR was also performed as described above on human RNA extracted from fetal and adult adrenals. Reaction was terminated at 27, 30 and 33 cycles. PCR products were run on a $1 \%$ agarose gel.

\section{Results}

\section{H295R cells and adrenal tissue express members of the Src tyrosine kinase family}

A semi-quantitative RT-PCR for the Src family members, Src, Fyn and Yes demonstrated transcript expression in H295R cells, human fetal adrenal and adult adrenal tissue. H295R cells exhibited a higher expression for Yes compared with Src and Fyn. Comparison of fetal and adult adrenal suggests that the adult adrenal gland has higher expression of Src compared with the fetal adrenal (Fig. 1).

\section{Regulation of adrenal cell steroidogenesis}

Steroid hormone production was studied using the H295R adrenal cell line as well as primary cultures of human adult adrenocortical cells. To examine the effects of PP2 on steroidogenesis, H295R cells were treated with PP2 and steroid accumulation monitored in the experimental medium. The effects of PP2 were initially examined on basal levels of steroidogenesis. H295R cells responded to PP2 treatment with a concentration- and timedependent increase in the production of DHEA and DHEA-S (Figs 2 and 3). Interestingly cortisol was dramatically inhibited in the presence of PP2. Half-maximal inhibition of cortisol production was observed at a PP2 concentration between 1 and $3 \mu \mathrm{M}$, which was the same range for half-maximal stimulation of DHEA and DHEA-S (Fig. 2). Stimulation of DHEA and DHEA-S production occurred within respectively 6 and $24 \mathrm{~h}$ of PP2 treatment (Fig. 3). Chronic treatment of H295R cells for $48 \mathrm{~h}$ with PP2 $(10 \mu \mathrm{M})$ increased DHEA and DHEA-S production by 6 - and $2 \cdot 5$-fold 


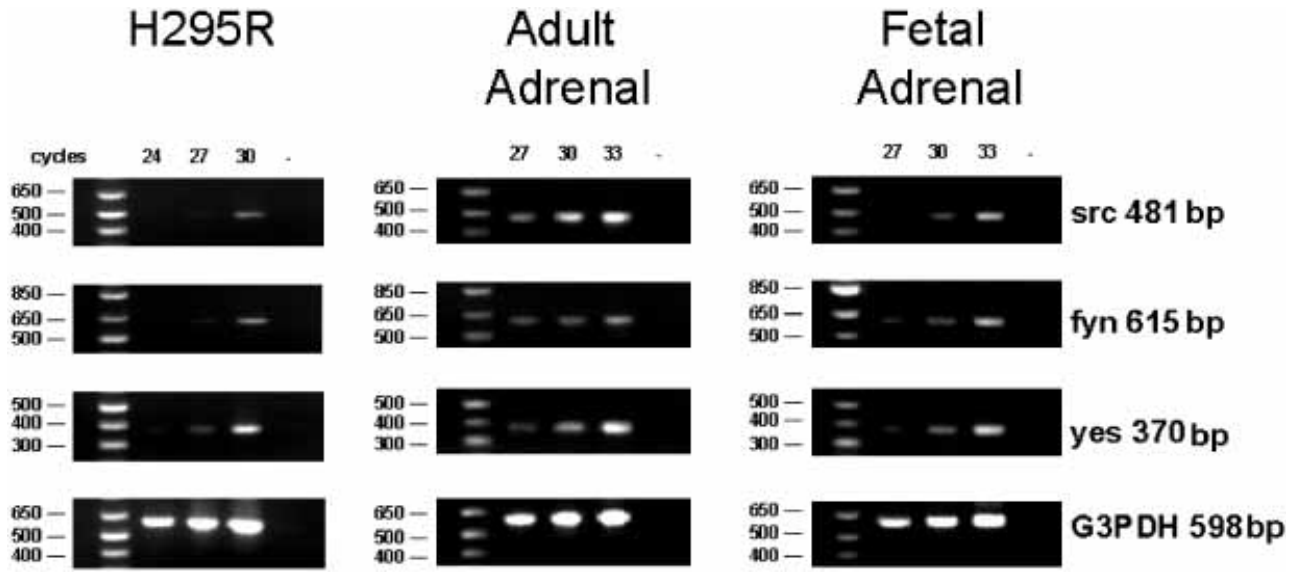

Figure 1 Semi-quantitative RT-PCR analysis of the levels of Src, Fyn and Yes tyrosine kinases in adrenal tissue and H295R adrenal cells. Using G3 PDH as a reference gene we compared relative mRNA expression levels of Src, Fyn and Yes in H295R cells as well as in human fetal and adult adrenal. Transcript levels in H295R cells revealed a different pattern of gene expression with higher levels for Yes. The size of the amplified fragments are indicated as well as the cycle number.

DHEA

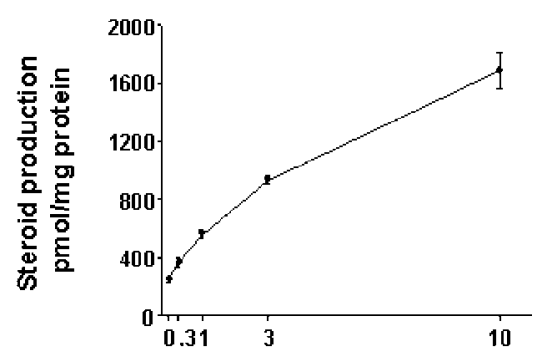

DHEA-S

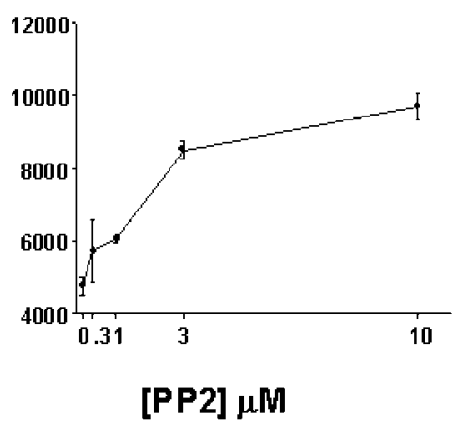

Cortisol

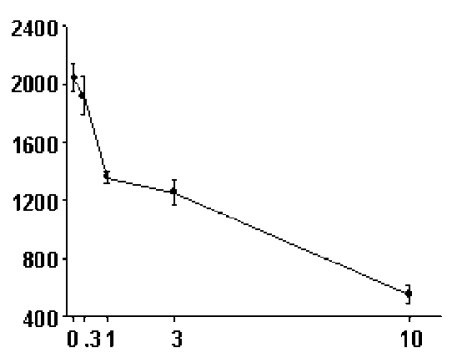

Figure 2 Concentration-dependent effects of PP2 on steroid production in H295R cells. Cells were incubated for $48 \mathrm{~h}$ with PP2 $(0 \cdot 3-10 \mu \mathrm{M})$. The DHEA, DHEA-S and cortisol content of the medium was determined by RIA and normalized to the tissue culture well protein content. Data points represent the means \pm S.E. of values from four separate wells expressed as pmol steroid/mg protein. Similar results were observed in two additional experiments.

respectively, while cortisol production was reduced by $80 \%$ (Fig. 3).

The effects of PP2 were next examined on agonist stimulation of steroidogenesis in H295R cells. We have previously shown that dbcAMP stimulates H295R cell production of both glucocorticoids and adrenal androgens (Rainey et al. 1993). Treatment for $48 \mathrm{~h}$ with dbcAMP $(1 \mathrm{mM})$ increased production of DHEA by $6 \cdot 8$-fold, DHEA-S by $3 \cdot 9$-fold and cortisol by $4 \cdot 3$-fold (Fig. 4). PP2 $(10 \mu \mathrm{M})$ significantly increased the production of DHEA and DHEA-S over dbcAMP alone. In contrast, PP2 inhibited dbcAMP stimulation of cortisol production to $15 \%$ of the levels observed with dbcAMP alone.

Primary cultures of human adult adrenal cells were also treated with PP2. Basal levels of steroid hormone production were lower in the primary cultures than observed in the H295R cells (Fig. 5). However, PP2 $(10 \mu \mathrm{M})$ was able to stimulate basal production of DHEA and DHEA-S. Treatment with dbcAMP $(1 \mathrm{mM})$ increased both cortisol and adrenal androgen production. Treatment with a combination of dbcAMP and PP2 gave a further increase in androgen production while cortisol was inhibited (Fig. 5). Thus the effects of PP2 on human 
DHEA

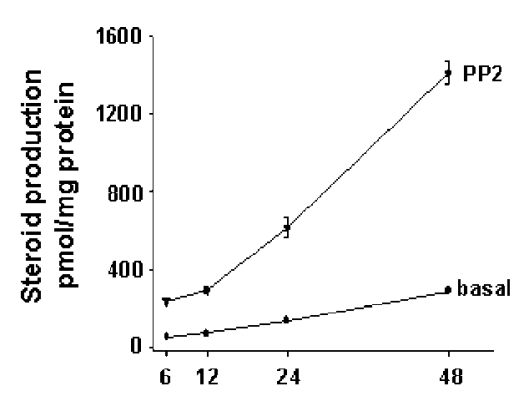

DHEA-S

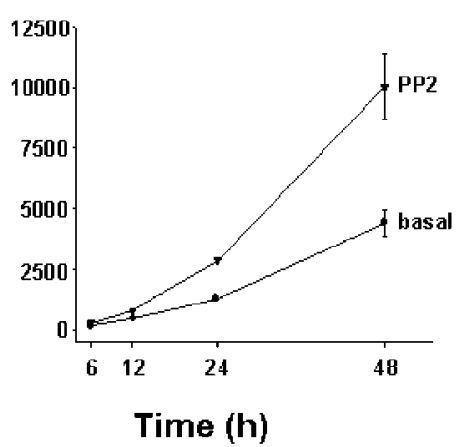

Cortisol

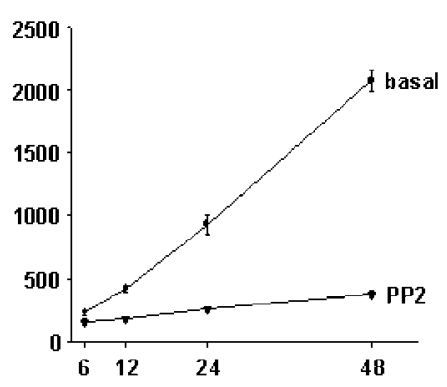

Figure 3 Time-dependent effects of PP2 on steroid production in H295R adrenal cells. H295R cells were incubated for the times shown with PP2 $(10 \mu \mathrm{M})$. The DHEA, DHEA-S and cortisol content of the medium was determined by RIA and normalized to the tissue culture well protein content. Data points are the means \pm S.E. of values from four separate wells expressed as pmol steroid/mg protein. Similar results were observed in two additional experiments.

DHEA

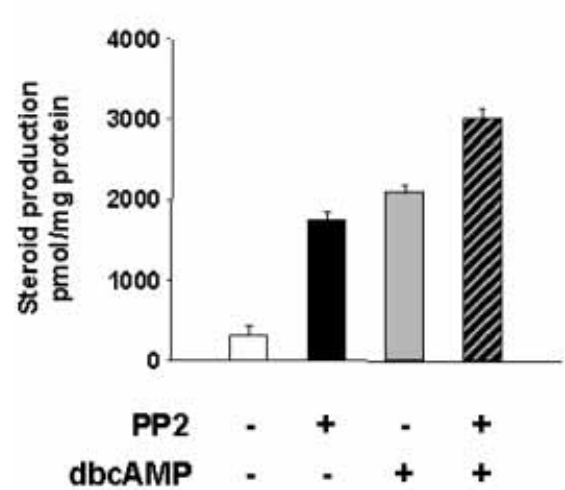

DHEA-S

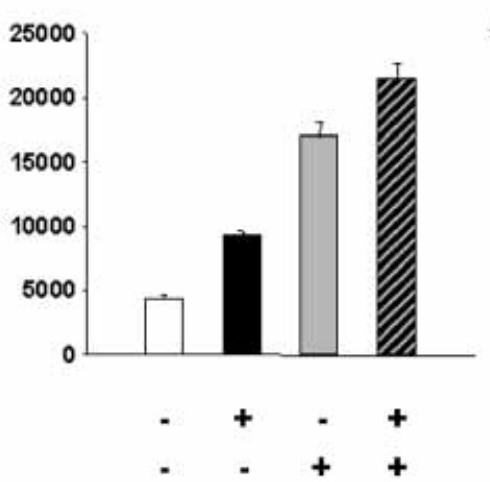

Cortisol

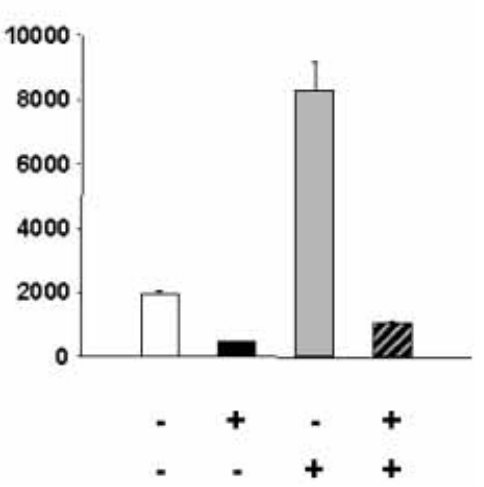

Figure 4 Effects of PP2 on agonist-stimulated steroid production in H295R cells. Cells were incubated for $48 \mathrm{~h}$ in basal condition, with PP2 $(10 \mu \mathrm{M})$, with dbcAMP $(1 \mathrm{mM})$ and with PP2 $(10 \mu \mathrm{M})$ plus dbcAMP $(1 \mathrm{mM})$. The steroid content of the medium was determined by RIA and normalized to the tissue culture well protein content. Data points are the means \pm S.E. of values from four separate wells expressed as $\mathrm{pmol}$ steroid $/ \mathrm{mg}$ protein. Similar results were observed in two additional experiments.

adrenal cell primary cultures were similar to those seen using the H295R adrenal cell model.

\section{Effects of PP2 on StAR protein expression}

Stimulation of adrenal steroid hormone production, regardless of the adrenal steroid, relies on an induction of cholesterol conversion to pregnenolone within the mitochondria. This rate-limiting step relies on the expression of StAR protein. We hypothesized that the acute effects of PP2 were through increased expression of StAR protein leading to increased DHEA synthesis. Western analysis for StAR protein using H295R cell lysates showed a time-dependent increase in protein levels that reached the same level of induction observed for dbcAMP (Fig. 6). These data support the idea that the PP2 induction of adrenal androgen production occurs as a result of StAR induction.

\section{Transcript levels for steroid-metabolizing enzymes}

To further define the mechanisms by which PP2 chronically affects steroidogenesis, we examined the level of transcript expression for the genes encoding steroidogenic enzymes. CYP11A and StAR mRNA 
DHEA

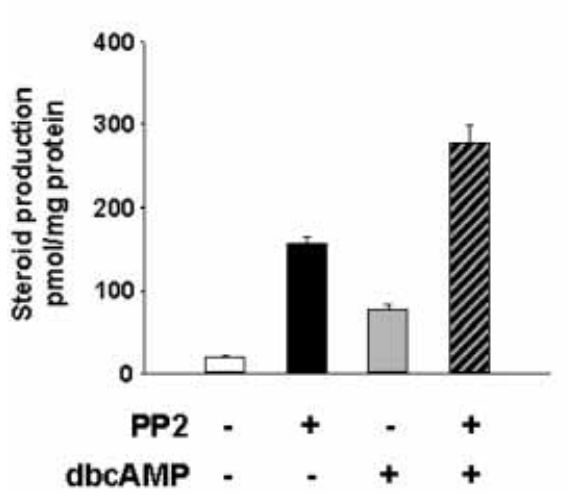

DHEA-S

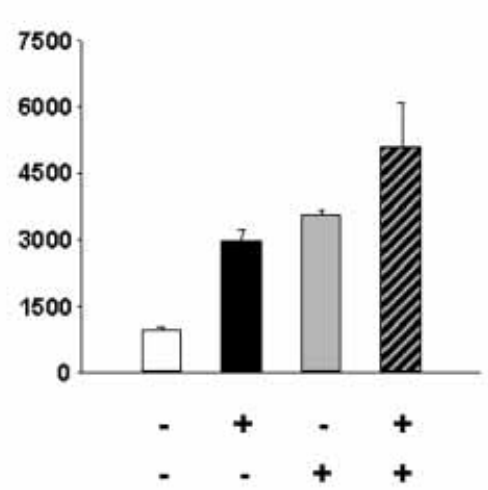

Cortisol

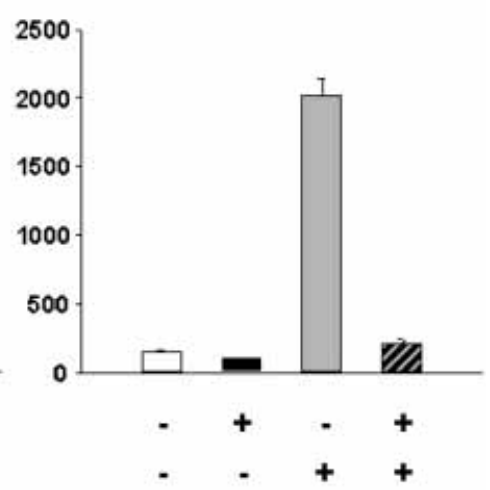

Figure 5 Effects of PP2 on primary cultures of human adrenal cells. Primary adrenal cells were incubated for $48 \mathrm{~h}$ in basal condition with PP2 $(10 \mu \mathrm{M})$, dbcAMP $(1 \mathrm{mM})$ or PP2 $(10 \mu \mathrm{M})$ plus dbcAMP $(1 \mathrm{mM})$. The steroid content of the medium was determined by RIA and normalized to the amount of cell protein on each tissue culture well. Data points are the means \pm S.E. of values from four separate wells expressed as pmol steroid/mg protein. Similar results were observed in two additional experiments.

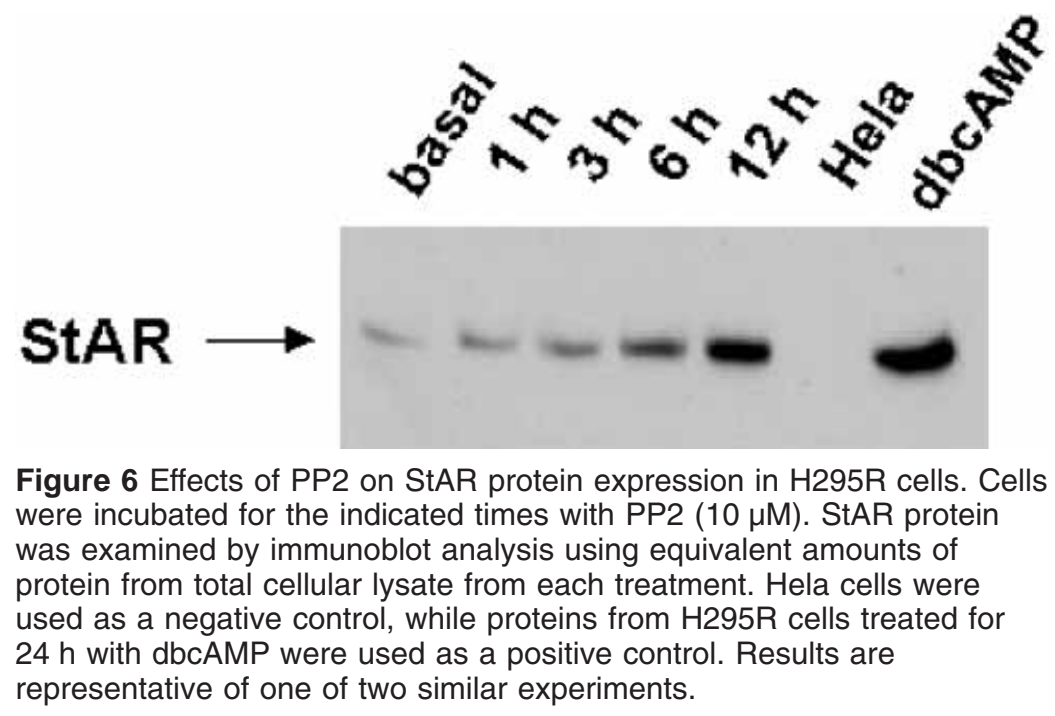

levels increased by 2 - and $1 \cdot 7$-fold respectively after $12 \mathrm{~h}$ of PP2 treatment, levels that were maintained after $24 \mathrm{~h}$ of treatment (Fig. 7). PP2 increased the level of CYP17 transcript in a time-dependent manner with a 3.7-fold increase seen at $24 \mathrm{~h}$ (Fig. 7). Treatment with PP2 did not significantly change the low basal level of HSD3B2 mRNA at any of the times tested (Fig. 7). The expression of both CYP17 and HSD3B2 transcripts can be increased by treatment with dbcAMP. Treatment with dbcAMP increased the level of HSD3B2 transcript by $2 \cdot 5$-fold and CYP17 by 4 -fold. Importantly, PP2 inhibited dbcAMP induction of
HSD3B2 mRNA to levels observed in control cells (Fig. 8). This is in contrast to the effects of PP2 on CYP17 mRNA levels, which were induced by 8-fold under co-treatment with dbcAMP together with PP2 (Fig. 8).

\section{Effects of dominant-negative Src on CYP17 expression}

To confirm that an inhibition of Src tyrosine kinase stimulated the expression of CYP17, H295R cells were transfected with an expression vector for an inactive (dominant-negative) Src. H295R cells were 

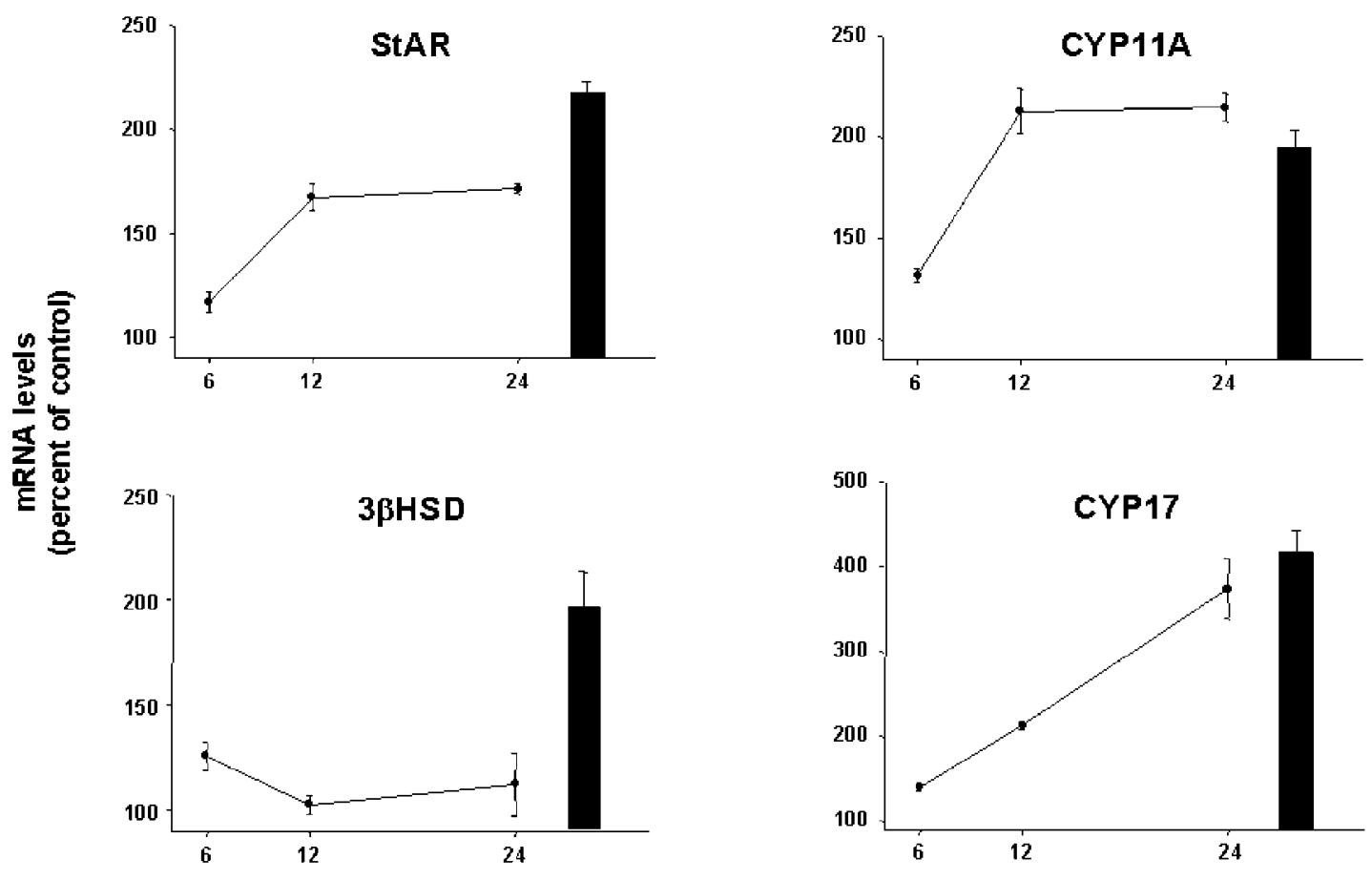

\section{Time (h)}

Figure 7 Effects of PP2 on the time-course levels of transcripts for CYP11A1, CYP17, HSD3B2 and StAR. H295R cells were incubated for times shown with PP2 $(10 \mu \mathrm{M})$ and with dbcAMP $(1 \mathrm{mM})$ for $24 \mathrm{~h}$ as designated by the black bar. Medium was then removed and cellular RNA was recovered and subjected to Northern analysis. Results were quantified directly by phosphoimager analysis and normalized to G3 PDH mRNA in the same lane. mRNA expression following PP2 treatment was compared with mRNA levels in basal conditions (control, 100\%). Data points are the means \pm S.E. of values obtained from three separate experiments.

electroporated with the dominant-negative Src in an expression vector that also encoded GFP. Cells expressing GFP were selected with flow cytometry, allowing us to have a pure population of cells containing the mutated Src. Western analysis of proteins extracted from GFP-expressing H295R cells revealed a high level of dominant-negative Src expression (Fig. 9). As was seen with PP2 inhibition of Src, cells expressing the dominant-negative Src construct were found to increase CYP17 expression (Fig. 9).

\section{Discussion}

Progress in defining the mechanisms that regulate DHEA(S) production has been hampered by the fact that adrenal secretion of $\operatorname{DHEA}(\mathrm{S})$ is absent or very low in all mammals except primates (Guillemette et al. 1996). Studies on the in vivo regulation of DHEA(S) synthesis have therefore been limited to humans and non-human primates. This has limited the progress in defining mechanisms that regulate adrenal androgen production and has made it important to develop in vitro cell culture models that retain DHEA(S) production. Culture systems that continue to produce DHEA(S) include primary cultures of human fetal adrenal cells (Doody et al. 1990, Rainey et al. 1992b, Mesiano \& Jaffe 1997b) as well as cultures of human adult adrenal cells (Ilvesmaki \& Voultilainen 1991). We and others have shown that the human H295R adrenocortical tumor cell line produces DHEA(S), making it the first readily available model to study the production of adrenal androgens (Rainey et al. 1993, Staels et al. 1993). Using these in vitro model 
$3 \beta \mathrm{HSD}$

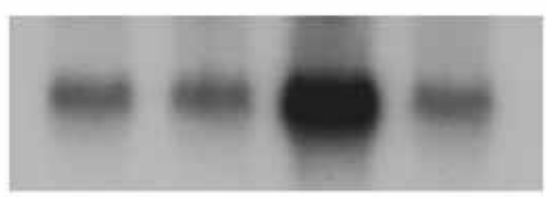

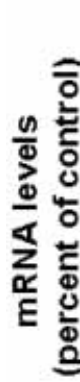

कิ

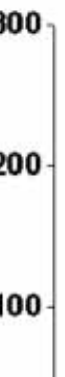

1

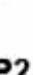

dbcAMP

Figure 8 Effects of PP2 on agonist-stimulated transcript levels of HSD3B2 and CYP17. H295R cells were incubated for $24 \mathrm{~h}$ with PP2 $(10 \mu \mathrm{M})$ dbcAMP $(1 \mathrm{mM})$ and with PP2 $(10 \mu \mathrm{M})$ plus dbcAMP $(1 \mathrm{mM})$. Cellular RNA was then recovered and subjected to Northern analysis. Results were quantified directly by phosphoimager and compared with levels of G3PDH mRNA in the same lane. Data points are the means \pm S.E. of values from three separate experiments; the insert is representative of one of the three experiments.

systems, several agents have been found that can stimulate the production of DHEA(S).

\section{Potential regulators of adrenal androgen production}

There is considerable in vivo evidence that adrenocorticotropin (ACTH) is necessary but not sufficient for the production of adrenal androgens. This is supported by the observation that patients with mutations in the ACTH receptor have low DHEA(S) production (Weber et al. 1997). However, ACTH levels do not change at times when circulating DHEA levels change drastically, such as during adrenarche or aging (Apter et al. 1979). In vitro studies have shown that $\mathrm{ACTH}$, as well as any agonists of cAMP, will stimulate $\operatorname{DHEA}(\mathrm{S})$ production. However, ACTH also has a potent stimulatory effect on the production of cortisol, suggesting that other factors must be involved in the specific regulation of $\mathrm{DHEA}(\mathrm{S})$ production.
Therefore, the cAMP signaling system does not appear to be able to specifically regulate DHEA(S) production.

Recent studies have focused on a role for CRH in the regulation of adrenal androgen production, particularly in the fetus (McLean \& Smith 2001). $\mathrm{CRH}$ is produced in high levels by the fetal placenta and adrenal cells respond to $\mathrm{CRH}$ with an increase in DHEA-S and to a lesser degree cortisol (Smith et al. 1998, Parker et al. 1999). The mechanism of CRH signaling appears to be through an increase in inositol phosphate generation, which should increase intracellular calcium and most likely protein kinase $\mathrm{C}$ (Chakravorty et al. 1999). While it has been proposed that protein kinase $\mathrm{C}$ is involved in fetal adrenal androgen production, this hypothesis needs further study due to conflicting reports on the effects of protein kinase $\mathrm{C}$ on adrenal steroidogenesis. We, and others, have shown that activation of protein kinase $\mathrm{C}$ by phorbol ester will increase the basal level of 


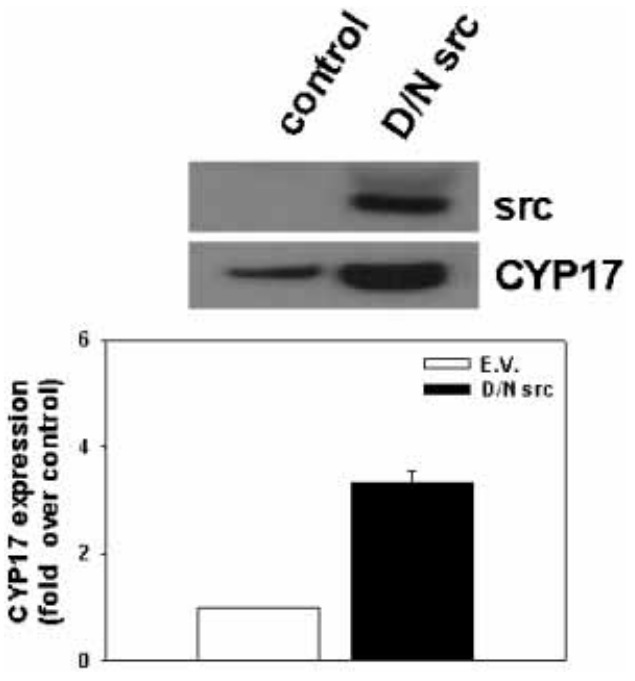

Figure 9 Effects of dominant-negative Src on CYP17 expression. Cells were electroporated with a vector containing GFP alone (control, empty vector) or the same vector containing the sequence for a dominant-negative Src (D/N src). GFP-expressing cells were isolated $48 \mathrm{~h}$ later and used for immunoblot analysis for CYP17 and Src. Results shown are from one of two similar experiments. The graphed data represent the average \pm the range from densitometric analysis on the two experiments.

production of DHEA-S (Mason et al. 1986, McAllister et al. 1988, Ilvesmaki \& Voutilainen 1991, Rainey et al. 1992a, Bird et al. 1998). However, phorbol ester (TPA) also increases basal levels of cortisol production suggesting that this signaling pathway is not a specific stimulator of adrenal androgen production. In addition, when TPA is added with agonists the production of adrenal androgens is strongly inhibited (Bird et al. 1998). This inhibition is in part due to the ability of protein kinase $\mathrm{C}$ to induce the expression of HSD3B2.

A potential role for steroids, particularly estradiol, in promoting adrenal androgen production has been suggested (Fujieda et al. 1982, Mesiano \& Jaffe 1993, Gell et al. 1998b). The role of estradiol is supported by in vitro studies where high concentrations of estradiol have been shown to enhance basal and ACTH-stimulated DHEA(S) production. The concentrations of estradiol that are necessary to promote $\mathrm{DHEA}(\mathrm{S})$ production ( $\mu \mathrm{M}$ range) are actually found in vivo in the human fetal circulation where adrenal androgen production is high (Fujieda et al. 1982, Winter \& Smail
1983, Mesiano \& Jaffe 1993, Gell et al. 1998b). The mechanism of high-dose estradiol action on DHEA production appears to be through a direct inhibition of HSD3B2 enzyme activity. There are two HSD3B enzymes (type 1 and 2) but the adrenal expresses only type 2 (HSD3B2). While HSD3B2 is not needed for the production of either DHEA or DHEA-S, the activity of this enzyme directly impacts adrenal androgen synthesis by competition for steroid substrate with CYP17.

\section{PP2 causes adrenal cells to adopt a DHEA(S)-secreting phenotype}

The major sources of adrenal androgens are the fetal zone in the fetus and the zona reticularis in the adult. Careful study of the expression patterns of the enzymes involved in steroid biosynthesis has shown several similarities between the fetal zone and zona reticularis. These include high expression of CYP11A and CYP17, the enzymes involved in $\operatorname{DHEA}(\mathrm{S})$ biosynthesis. In addition, adrenal androgen-producing cells have low expression of HSD3B2 protein and mRNA (Gell et al. 1998a, Suzuki et al. 2000, Narasaka et al. 2001, Rainey et al. 2001). The ability of PP2 to chronically stimulate adrenal androgen production made us hypothesize that PP2 could cause the H295R cell to assume the phenotype of a DHEA(S)-producing cell. Therefore, we examined the effects of PP2 on steroidogenic enzyme expression within adrenal cells. PP2 stimulated expression of StAR, CYP11Al and CYP17, which are needed to maximize DHEA(S) biosynthesis. However, these enzymes are needed for cortisol and DHEA(S) production. In contrast to these proteins, HSD3B2 is needed for cortisol but not DHEA(S) biosynthesis and differential expression of HSD3B2 has been shown to influence DHEA biosynthesis (Bird et al. 1996). PP2 did not affect basal HSD3B2 transcript levels, which are extremely low in the H295R cell. However, PP2 blocked the ability of cAMP analogues to increase HSD3B2 mRNA levels. Under both basal and cAMP-stimulated conditions, PP2 increased the GYP17 to HSD3B2 ratio. The resulting decrease in the ability of HSD3B2 to compete with CYP17 for substrate helps explain the resulting increase in $\mathrm{DHEA}(\mathrm{S})$ production. Taken together these data suggest that PP2 treatment (and Src inhibition) causes the cultured adrenal cells to develop a reticularis-like phenotype. 


\section{Is PP2 acting through Src tyrosine kinases?}

Src is the most understood member of a family of eight tyrosine kinases that regulate cellular responses to extracellular stimuli (Brown \& Cooper 1996, Abram \& Courtneidge 2000). In mammals this family consists of Src, Fyn and Yes that are ubiquitously expressed, whereas other members, Lck, Hck, Fgr, Lyn and Blk, have more tissuerestricted expression mainly in hematopoietic cells. Using semi-quantitative RT-PCR we examined expression of Src, Fyn and Yes in RNA isolated from human adrenals. Both human adrenal and H295R cells were found to express Src tyrosine kinase.

To determine the role of Src in steroidogenesis we initially tested the effects of the inhibitor PP2. PP1 and PP2 are recently developed inhibitors that show specificity for the Src family of kinases (Hanke et al. 1996, Liu et al. 1999). Detailed studies of these inhibitors have shown that they rely on a single region revolving around Thr338 (Liu et al. 1999) that is found in all Src family members. Detailed analysis of the inhibitors has confirmed that they are powerful tools to study the roles of Src tyrosine kinases in differentiation and cell division. However, there is still the concern with the use of any kinase inhibitor of potential collateral effects on other signaling pathways. Indeed, certain of the less-specific tyrosine kinase inhibitors have been shown to block enzymatic activity of HSD3B2 (Wong \& Keung 1999, Sirianni et al. 2001). Using the H295R cell line, we directly compared the effects of PP2 and genistein on the activity of HSD3B2 and demonstrated that PP2 had little direct effect, while genistein was a potent inhibitor. The inhibitory effects of genistein on HSD3B2 enzyme activity may partially explain the report by Mesiano et al. (1999) that genistein could promote adrenal androgen production and inhibit cortisol production.

In order to further confirm the role of Src, we designed experiments to inhibit Src tyrosine kinases by an independent mechanism. H295R cells were transfected with an expression vector containing a mutated form of Src tyrosine kinase that acts as a dominant inhibitor of all Src tyrosine kinase family members. The expression of CYP17 was found to increase in cells transfected with the dominantnegative Src protein, which was in good agreement with the findings using the Src tyrosine kinase inhibitor, PP2. Taken together these data support the hypothesis that PP2 stimulated adrenal cell cultures to produce DHEA(S) as a result of effects on Src tyrosine kinase inhibition.

Currently the physiological mechanisms by which adrenal cells might control Src tyrosine kinase activity and thereby regulate DHEA(S) production are not known. However, a recent study examining the regulation of the 17,20 lyase activity of CYP17 appears to provide an additional clue into the regulation of adrenal androgen production. Pandey et al. (2003) showed that protein phosphatase $2 \mathrm{a}$ is able to dephosphorylate CYP17 and decrease the 17,20 lyase activity of this enzyme, which would also decrease production of DHEA. Interestingly, this protein phosphatase is also able to inhibit Src tyrosine kinase activity (Yokoyama \& Miller 2001). Further studies on signaling pathways that inhibit both the activation of protein phosphates 2a and Src tyrosine kinase may provide much needed information on the mechanisms controlling adrenal androgen production.

In summary, it is clear that the level of circulating DHEA(S) follows a trend during development and aging that is distinct from other adrenal steroids or gonad-derived estrogens and androgens. In many regards, the mechanisms regulating $\mathrm{DHEA}(\mathrm{S})$ synthesis continue to represent one of the most intriguing mysteries of endocrine physiology. The effects of PP2 represent the first description of a treatment regime, although pharmacological, that specifically stimulates DHEA(S) production, while inhibiting production of cortisol. Extending the understanding of how Src kinase is regulated in adrenal cells may provide information on the physiological regulators of adrenal DHEA(S) biosynthesis.

\section{Acknowledgements}

Support for this study was provided by grants from the National Institutes of Health grants HD11149 and DK43140 to W E R.

\section{References}

Abram CL \& Courtneidge SA 2000 Src family tyrosine kinases and growth factor signaling. Experimental Cell Research 254 1-13.

Apter D, Pakkerinen A, Hammond GI \& Vihko R 1979

Adrenocortical function and puberty, serum ACTH cortisol and dehydroepiandrosterone in girls and boys. Acta Pediatrica Scandinavia $69599-606$. 
Biason-Lauber A, Zachmann M \& Schoenle EJ 2000 Effect of leptin on CYP17 enzymatic activities in human adrenal cells: new insights in the onset of adrenarche. Endocrinology 141 1446-1454.

Bird IM, Mathis JM, Mason JI \& Rainey WE $1995 \mathrm{Ca}^{2+}$-regulated expression of steroid hydroxylases in H295R human adrenocortical cells. Endocrinology 136 5677-5684.

Bird IM, Pasquarette MM, Rainey WE \& Mason JI 1996 Differential control of 17 alpha-hydroxylase and 3 beta-hydroxysteroid dehydrogenase expression in human adrenocortical H295R cells. Fournal of Clinical Endocrinology and Metabolism 81 2171-2178.

Bird IM, Mason JI \& Rainey WE 1998 Battle of the kinases: integration of adrenal responses to cAMP, DG and $\mathrm{Ca}^{2+}$ at the level of steroidogenic cytochromes $\mathrm{P} 450$ and HSD3B2 expression in H295R cells. Endocrine Research 24 345-354.

Brown MT \& Cooper JA 1996 Regulation, substrates and functions of Src. Biochimica et Biophysica Acta 1287 121-149.

Chakravorty A, Mesiano S \& Jaffe RB 1999 Corticotropin-releasing hormone stimulates P450 17 alpha-hydroxylase/17,20-lyase in human fetal adrenal cells via protein kinase C. Fournal of Clinical Endocrinology and Metabolism 84 3732-3738

Doody KM, Carr BR, Rainey WE, Byrd W, Murry BA, Strickler RC, Thomas JL \& Mason JI 19903 beta-hydroxysteroid dehydrogenase/isomerase in the fetal zone and neocortex of the human fetal adrenal gland. Endocrinology 126 2487-2492.

Endoh A, Kristiansen SB, Casson PR, Buster JE, Hornsby PJ 1996 The zona reticularis is the site of biosynthesis of dehydroepiandrosterone and dehydroepiandrosterone sulfate in the adult human adrenal cortex resulting from its low expression of 3 $\beta$-hydroxysteroid dehydrogenase. Fournal of Clinical Endocrinology and Metabolism 81 3558-3565.

Fujieda K, Faiman C, Feyes FI \& Winter JSD 1982 The control of steroidogenesis by human fetal adrenal cells in tissue cultures. IV. The effects of exposure to placental steroids. Fournal of Clinical Endocrinology and Metabolism 54 89-94.

Gell JS, Carr BR, Sasano H, Atkins B, Margraf L, Mason JI \& Rainey WE 1998a Adrenarche results from development of a $3 \beta$-hydroxysteroid dehydrogenase-deficient adrenal reticularis. Fournal of Clinical Endocrinology and Metabolism 83 3695-3701.

Gell JS, Oh J, Rainey WE \& Carr BR $1998 b$ Effect of estradiol on DHEAS production in the human adrenocortical cell line, H295R. Fournal of the Society for Gynecologic Investigation 5 144-148.

Guillemette C, Hum DW, Belanger A 1996 Levels of plasma C19 steroids and 5 alpha reduced C19 steroid glucuronides in primates, rodents, and domestic animals. American Fournal of Physiology 271 E348-E353.

Hanke JH, Gardner JP, Dow RL, Changelian PS, Brissette WH, Weringer EJ, Pollok BA \& Connelly PA 1996 Discovery of a novel, potent, and Src family-selective tyrosine kinase inhibitor. Study of Lck- and FynT-dependent T cell activation. Fournal of Biological Chemistry 271 695-701.

Ilvesmaki V, Voutilainen R 1991 Interaction of phorbol ester and adrenocorticotropin in the regulation of steroidogenic $\mathrm{p} 450$ genes in human fetal and adult adrenal cell cultures. Endocrinology 128 $1450-1458$.

Liu Y, Bishop A, Witucki L, Kraybill B, Shimizu E, Tsien J, Ubersax J, Blethrow J, Morgan DO \& Shokat KM 1999 Structural basis for selective inhibition of Src family kinases by PP1. Chemistry and Biology 6 671-678.

Mason JI, Carr BR \& Rainey WE 1986 The action of phorbol ester on steroidogenesis in cultured human fetal adrenal cells. Endocrine Research 12 447-467.

Mason JI, Bird IM \& Rainey WE 1995 Adrenal androgen biosynthesis with special attention to P450c17. Annals of the New York Academy of Sciences $\mathbf{7 7 4}$ 47-58.

McAllister JM \& Hornsby PJ 1988 Dual regulation of 3 betahydroxysteroid dehydrogenase, 17 alpha-hydroxylase and dehydroepiandrosterone sulfotransferase by adenosine $3^{\prime}, 5^{\prime}$-monophosphate and activators of protein kinase $\mathrm{C}$ in cultured human adrenocortical cells. Endocrinology 122 2012-2018.

McKenna TJ, Fearon U, Clarke D \& Cunningham SK 1997 A critical review of the origin and control of adrenal androgens. Baillieres Clinical Endocrinology and Metabolism 11 229-248.

McLean M \& Smith R 2001 Corticotropin-releasing hormone and human parturition. Reproduction $121493-501$.

Mesiano S \& Jaffe RB 1993 Interactions of insulin-like growth factor-II and estradiol directs steroidogenesis in the human fetal adrenal toward dehydroepiandrosterone sulfate production. Fournal of Clinical Endocrinology and Metabolism 77 754-758.

Mesiano S \& Jaffe RB 1997 a Developmental and functional biology of the primate fetal adrenal cortex. Endocrine Reviews 18 378-403.

Mesiano S \& Jaffe RB $1997 b$ Role of growth factors in the developmental regulation of the human fetal adrenal cortex. Steroids $\mathbf{6 2} 62-72$.

Mesiano S, Katz SL, Lee JY \& Jaffe RB 1999 Phytoestrogens alter adrenocortical function: genistein and daidzein suppress glucocorticoid and stimulate androgen production by cultured adrenal cortical cells. Fournal of Clinical Endocrinology and Metabolism $842443-2448$.

Narasaka T, Suzuki T, Moriya T \& Sasano H 2001 Temporal and spatial distribution of corticosteroidogenic enzymes immunoreactivity in developing human adrenal. Molecular and Cellular Endocrinology 174 111-120.

Nieschlag E, Loriaux DL, Ruder HJ, Zucker IR, Kirschner MA \& Lipsett MB 1973 The secretion of dehydroepiandrosterone and dehydroepiandrosterone sulfate in man. Fournal of Clinical Endocrinology 57 123-134.

Pandey AV, Mellon SH \& Miller WL 2003 Protein phosphatase 2A and phosphoprotein SET regulate androgen production by P450c17. Fournal of Biological Chemistry 278 2837-2844.

Parker CR Jr 1999 Dehydroepiandrostenedione sulfate production in the human adrenal during development and aging. Steroids 64 640-647.

Parker CR Jr, Stankovic AK \& Goland RS 1999 Corticotropinreleasing hormone stimulates steroidogenesis in cultured human adrenal cells. Molecular and Cellular Endocrinology 155 19-25.

Parker LN \& Odell WD 1980 Control of adrenal androgen secretion. Endocrine Reviewes 1 392-407.

Pezzi V, Clark BJ, Ando S, Stocco DM \& Rainey WE 1996 Role of calmodulin-dependent protein kinase II in the acute stimulation of aldosterone production. Fournal of Steroid Biochemistry and Molecular Biology 58 417-424.

Rainey WE, Bird IM \& Mason JI 1992a Angiotensin II-directed glomerulosa cell function in fetal adrenal cells. Fournal of Steroid Biochemistry and Molecular Biology 43 847-854.

Rainey WE, Bird IM, Mason JI \& Carr BR $1992 b$ Angiotensin II receptors on human fetal adrenal cells. American foumal of Obstetrics and Gynecology 167 1679-1685.

Rainey WE, Bird IM, Sawetawan C, Hanley NA, McCarthy JL, McGee EA, Wester R \& Mason JI 1993 Regulation of human adrenal carcinoma cell (NCI-H295) production of C19 steroids. Fournal of Clinical Endocrinology and Metabolism 77 731-737.

Rainey WE, Carr BR, Wang ZN \& Parker CR Jr 2001 Gene profiling of human fetal and adult adrenals. Fournal of Endocrinology $171209-215$.

Schiebinger RJ, Albertson BD, Cassorla FG, Bowyer DW, Geelhoed GW, Cutler GB \& Loriaux DL 1981 The developmental changes in plasma adrenal androgens during infancy and adrenarche are associated with changing activities of adrenal microsomal 17-hydroxylase and 17,20-desmoslase. Fournal of Clinical Investigation 67 1177-1182.

Sirianni R, Carr BR, Pezzi V \& Rainey WE 2001 A role for src tyrosine kinase in regulating adrenal aldosterone production. Fournal of Molecular Endocrinology 26 207-215. 
Smith R, Mesiano S, Chan EC, Brown S \& Jaffe RB 1998 Corticotropin-releasing hormone directly and preferentially stimulates dehydroepiandrosterone sulfate secretion by human fetal adrenal cortical cells. Fournal of Clinical Endocrinology and Metabolism 83 2916-2920.

Staels B, Hum DW \& Miller WL 1993 Regulation of steroidogenesis in NCI-H295 cells: a cellular model of the human fetal adrenal. Molecular Endocrinology 7 423-433.

Suzuki T, Sasano H, Tadeyama J, Kaneko C, Freije WA, Carr BR \& Rainey WE 2000 Developmental changes of steroidogenic enzymes in human adrenal cortex: immunohistochemical studies. Clinical Endocrinology 53 739-747.

Weber A, Clark AJ, Perry LA, Honour JW \& Savage MO 1997 Diminished adrenal androgen secretion in familial glucocorticoid deficiency implicates a significant role for ACTH in the induction of adrenarche. Clinical Endocrinology 46 431-437.
Winter JSD \& Smail PJ 1983 Effects of ACTH and estradiol on steroid production by cultured adrenal cells from an anencephalic fetus and from normal adults. Steroids 42 677-685.

Wong CK \& Keung WM 1999 Bovine adrenal 3 beta-hydroxysteroid dehydrogenase (E.C. 1.1.1.145)/5-ene-4-ene isomerase (E.C. 5.3.3.1): characterization and its inhibition by isoflavones. Fournal of Biological Chemistry 71 191-202.

Yokoyama N \& Miller WT 2001 Inhibition of Src by direct interaction with protein phosphatase 2A. FEBS Letters $\mathbf{5 0 5}$ $460-464$.

Received in final form 5 March 2003 Accepted 10 March 2003 